10 years ESJ

Special edition

\title{
Assessing the Importance of Work for People with Disabilities at Auchan, Portugal
}

\author{
Marta Alexandra Gonçalves Nogueira \\ Doctoral Student - Universidad de Extremadura, Espanha \\ ESECS-IPLeiria, Portugal \\ Célia Maria Adão de Oliveira Aguiar de Sousa \\ ESECS-IPLeiria, CRID, CICS.NOVA.IPLeiria, Portugal
}

Doi: $10.19044 /$ esj.2021.v17n26p44

Submitted: 31 March 2021

Accepted: 10 June 2021

Published: 09 August 2021
Copyright 2021 Author(s)

Under Creative Commons BY-NC-ND

4.0 OPEN ACCESS

Cite As:

Gonçalves Nogueira M.A. \& Oliveira Aguiar de Sousa C.M.A. (2021). Assessing the Importance of Work for People with Disabilities at Auchan, Portugal. European Scientific Journal, ESJ, 17 (26), 44. https://doi.org/10.19044/esj.2021.v17n26p44

\begin{abstract}
The inclusion of People with Disabilities (PwD's) in the labor market is a challenge and a great opportunity for companies. This inclusion process has the power to generate a great social impact in the life of PwD since they can be paid and can also play an important role that makes them feel proud and useful to society. However, this community faces many difficulties both in their inclusion and during their day-to-day work. This paper, therefore, focuses on exploring and understanding how organizations welcome these workers, what emotions they feel and how they manage them, and how well communication takes place in this context. A mixed methodology was used, with recourse to qualitative and quantitative research. Fifty disabled workers and 314 of their co-workers, employees of the Auchan Portugal Group, participated in the study. The results showed that PwD's recognize their emotions when interacting with their co-workers, but most of them disguise themselves when they feel discomfort. The feeling/emotion that mostly characterizes the daily professional life of these people is pride, which refers to the importance that work plays in their daily lives. As for organizational communication, PwD's consider it to be accessible. It was also possible to
\end{abstract}


notice that although most PwD feel integrated, they suggest greater sensitivity from the employer, adapted work, and more accessibility in the workplace.

Keywords: Communication, disability, emotions, inclusion, workplace

\section{Introduction}

The inclusion of PwD's in the labor market is one of the most important points for their inclusion in society. For these people, work tends to strengthen their place in society, resulting in increased self-esteem to face existing social barriers (Prates, 2019).

PwD's constantly face several barriers when it comes to the issues of employment (Ruhindwa et al., 2016). These barriers start from job search and many of these people consider this stage to be complex, which generates a high level of stress (Rueda \& Andrade, 2016). This can be seen in the following areas: in recruitment and selection, whereby the hiring of these people is motivated only by the mandatory nature of the law and the low supply of vacancies (Lorenzo \& Silva, 2017); the lack of training by companies to work with PwD's (Carreras \& Moreno, 2011; Felizardo et al., 2016); and the lack of continuous follow-up of PwD's after their hiring (Rosa et al., 2019). Other difficulties experienced by PwD's are related to the physical conditions in the workplace (Anand \& Sevak, 2017) and the lack of communication within the company, which is often confusing or almost nonexistent (Borges et al., 2020; Roessler et al., 2017). However, the greatest difficulty experienced by this community is associated with the negative view that companies have about their inclusion in the labor market, since these people are often seen as less competent and unable to autonomously perform their work (Rohmer \& Louvet, 2018; Nosenko-Stein, 2017). In a study conducted by Vaquerano (2019), 70\% of PwD's revealed that they had experienced discrimination from the companies where they worked. Similar results were presented in the study by Quinn et al. (2016), where PwD's reported that their access to employment was influenced by perceived inefficiencies on the part of the employer.

However, there are studies that present alternative views, indicating that companies have a positive attitude towards hiring PwD's. According to Sundar et al. (2018), PwD's strive to work and overcome these barriers at work. These people are often seen as productive and focused (Rueda \& Andrade, 2016), with higher levels of organizational commitment (Vasconcelos \& Maranhão, 2020). They are well engaged and competitive with their hiring being an asset to organizations (González-González, 2017). In addition, studies have shown that hiring PwD's contributes to the company's social responsibility (Freitas et al., 2017; Huang \& Chen, 2015); improves the 
organization's image with customers (Leopoldino \& Coelho, 2017; Hahn et al., 2018); has a very positive impact; and promotes a culture of inclusion with employees (Scott et al., 2017).

However, the professional success of this population, as well as of all people in general, is also dependent on the management of their emotions and the organizational communication process (Arándiga, 2009). In relation to workers with disabilities, it was found that they often do not have the opportunity to express their emotions in a work context and, when they do, they end up being ignored (Coutinho et al., 2017). Many of these emotions relate to negative feelings experienced by PwD during their work day due to attitudes of prejudice and stigma from colleagues and managers. Such attitudes end up generating an increase in anxiety levels in PwD's, stress, difficulties in staying in the job (Shahin et al., 2020), and illegal dismissals and inability to demonstrate and put into practice their skills (Ripat \& Woodgate, 2017; Lieketseng \& Lorenzo, 2016). In the study by Pinheiro and Dellatorre (2015), it was found that colleagues and bosses had feelings of pity, fragility, and inferiority towards the PwD's. It was also verified in this study that PwD's avoided asking for any kind of help from colleagues or managers, mainly due to feelings of shame. In addition, many employers and co-workers of PwD's do not know how to deal with the emotions of these employees (Zappella, 2015). The reasons why PwD's omits what they feel in the workplace relate to prejudice, ignorance about the difference, and lack of compliance with legislation, making them feel uncomfortable (Santos, 2014). According to Sherbin and Kennedy's (2017) study, it was found that employees with disabilities who presented their ideas, emotions, and views to the organization were totally ignored by the organization.

Furthermore, some studies have shown that one of the great difficulties of PwD's in work integration is communication, which is very confusing and not very flexible (Borges et al., 2020). Oftentimes, these people remain isolated in the workplace and they communicate very little with colleagues and employers. PwD's are often excluded from work meetings since they consider that their participation is not important (Pinheiro \& Dellatorre, 2015). According to Sartika and Devita (2020), PwD's hardly reach leadership positions, not because of their limitations most of the time, but because of the communicational barriers they face in companies. This makes them experience more difficulty in their integration as a result of being often excluded from various functions (Barbra \& Mutswanga, 2014; Nota et al., 2013).

In contrast, it has been found that when there is a good relationship between co-workers, supervisors, and PwD's based on cooperation, respect, interaction and continuous support, as well as transparent and flexible 
communication between everyone, these people stay longer at work (Ripat \& Woodgate, 2017; Galle \& Mengden, 2016).

Therefore, this study aimed to understand how the labor market integrates PWDs, understand the emotions they feel and how they manage them throughout the work day, and learn how communication is processed in the workplace. To this end, the following specific objectives were defined: to know the degree of awareness that disabled workers have about their emotions in their daily interactions at work; to evaluate the communicative interactions of PwD's at work; and, finally, to verify to what extent they feel integrated into the company.

The purpose of this study is to contribute to the unanimous recognition of the right to work, since employment is of key importance in the process of social inclusion and economic emancipation of PWDs (Gonçalves \& Nogueira, 2012).

\section{Methodology}

The research was carried out at Auchan Portugal Group, which is an example of good practices in the area of recruitment and integration of PwD's.

Auchan (formerly Jumbo) is a brand belonging to the French group "Auchan", which acquired the Portuguese supermarket chains, Jumbo and Pão-de-Açúcar in 1996. The company's expansion policy in Portugal dictated the end of these two brands in the first half of 2019. The 147 stores in Portugal carry the name "Auchan", in an unequivocal concept of a single brand.

\subsection{Sample}

The sample was composed of $50 \mathrm{PwD}$ 's, employees of the hypermarkets of the Auchan Group from North to South of Portugal, mostly male (60\%) aged between 30 and 49 years. In relation to the type of disability, around half of the participants had Intellectual developmental disorders (50\%); followed by participants with Physical or Motor Disability (32\%); with Visual Disability (10\%) and Hearing Disability (8\%). Also participating in this study were 314 co-workers of PwD's, most of whom were female (74.4\%) aged between 30 and 49 years.

\subsection{Data Collection}

In this study, researchers chose the mixed methodology using semistructured interviews with disabled workers. The quantitative methodology used a questionnaire applied to co-workers of disabled workers. The interview script applied to the workers with disabilities consisted of five blocks of questions, and some of these blocks contained sub-paragraphs (block 2, 3, and 5). The initial part of the interview contained the sociodemographic characterization of the interviewee (name, age, gender, academic 
qualifications, type of disability, and number of months/years of work experience). The questionnaire applied to colleagues with disabilities contained closed-ended answers and was administered via Google Forms. In the initial part, this questionnaire contained sociodemographic data, academic qualifications, marital status, and socioprofessional data - professional position, area of work and place of work. The response possibilities varied on a scale of 1 to 5 (1=strongly disagree; $2=$ disagree; $3=$ neither agree nor disagree; $4=$ agree; $5=$ =strongly agree). The questionnaire consisted of four groups of questions: the first group contained 8 questions, the second 6 questions, the third 6 questions, and the last 7 questions.

\subsection{Data Analysis}

The treatment of the collected data included content analysis based on predefined categories of analysis arising from the literature review and the research objectives. The questionnaires applied were subjected to statistical analysis and content analysis. For the qualitative treatment of the data, NVivo 10.1.10. was used, which is a software used for qualitative and mixed-methods investigations (Bringer et al., 2004). For the statistical treatment of the data, SPSS 24 (Statistical Package for the Social Sciences) software was used. This is because it is considered an extremely powerful tool for manipulating and deciphering data collected through questionnaires (Gogoi, 2020).

\section{Results and Discussion}

This section provides analytical information regarding the survey undertaken on PwD's at Auchan, Portugal.

\subsection{Analysis of the Semi-structured Interview with PwD}

The results of the PwD's interview revealed that the feeling/emotion that mostly characterizes the daily work life of PwD's was pride. This can be verified through some excerpts: "Pride, in myself and in the work I'm doing, I'm following the rules of the day" (Supermarket operator); "Pride in what I do, I like what I do and they tell me I know how to work well, that I'm nice to the customers" (Supermarket operator).

One situation that usually generated intense emotion at work was "Being called attention for their work", as we can see in some examples reported by PwD's: "They come into my work to draw my attention to certain things and at the same time give me orders. It makes me sad. Nobody likes to be called to attention, right?" (Supermarket operator); "When work doesn't go the way I would like it to and I am called out by my colleagues for it, and often not in the best way" (Hypermarket operator). Other situations were: "Indifference, discrimination and exclusion", causing a feeling of sadness and frustration: "Clients don't want to be served by me because I have a disability. 
I often feel this indifference"; "Ifeel indifference from co-workers. I don't feel understood. It's not only integrating, but also understanding and defending" (Telephone Operator); "Sometimes I feel that I am excluded from work meetings. That makes me a little dissatisfied" (Telephone Operator).

Most PwD's do not clearly tell the other which emotion they felt and disguise the discomfort of the emotions they felt. They tell the other which behavior caused them discomfort.

As for organizational communication, PwD's consider it accessible. They did not find the communication channels confusing, and this can be verified in the speech of some of them: "My manager points out the tasks on the little sheet, and I see it. We also communicate by phone, these forms of communication now. There are also face-to-face meetings. We also talk to other sectors, and I know everybody." (Parapharmacy Assistant); "At first as I was ashamed it wasn't easy, I didn't know how they would react to me. But now it's easy. We use the phone to communicate (...), It doesn't cause me any confusion, it's fine with me" (Administrative Assistant- HR).

Most of the participants consider that the values and vision of the organization were clearly transmitted. This shows that there is a constant and collaborative interaction with the person in charge and with the colleagues. In their current job, most of the participants joined through entities. Thus, they feel included as they have attended vocational training and no specific adaptation has taken place.

In order to provide a greater professional insertion of PwD, they would like to see "More job opportunities" modified, "Greater sensitivity from employers" and "Work adapted to the person and his/her disability":

"I think we need to open people's minds more. Sometimes we are almost considered invalids and for us it's quite complicated (...). We can do as much, equal, or better than so-called normal people (...). We need better working conditions. It also is necessary to have more humanism. People are not human and there is discrimination in the world"(Cashier Operator).

"Change, improve the working conditions for each disability let's say (...). Who has to do this is the entity with the help of the state, because the state has to help in the integration of people. It can be done by asking for applications or arranging platforms that give access to get the benefits (...). Some incentives from the state for companies. That nowadays there are already, something more attractive for people, for companies to integrate people with disabilities" (Hypermarket operator).

Companies should have more faith in the ability of the disabled. To know if a person is good, you have to give them a chance, to know if they exceed your expectations. They put too many barriers and don't give the benefit of the doubt. We are not properly exploited in the labor market. They 
should give us more opportunities and give us a trial run" (Telephone Operator).

\subsection{Quantitative Analysis of the Questionnaire to PwD Co-workers}

The results of the questionnaire to PwD co-workers, regarding the four dimensions under study: General Perception of Hiring; Emotional Intelligence; Interpersonal Communication; and Integration/Insertion in the Workplace, indicated that the vast majority of PwD co-workers agreed with the items of the four dimensions. Therefore, this suggests a positive score with the themes under study. In the dimension General Perception of Hiring, the item "Hiring PwD contributes to the social responsibility of the company" was the one that obtained the highest degree of agreement from almost all the participants $(92.7 \%)$. In the following two items, they neither agreed nor disagreed on an average. Nevertheless, a part agreed with " $P w D$ have more difficulty understanding or performing a task" (30\%) and "PwD have less productivity" (23.6\%). In the Emotional Intelligence dimension, the item "I like to share my emotions with $P w D "$ only a little more than half agreed with this fact (55.7\%). In the dimension Interpersonal Communication, regarding the item "The PwD does not adopt inappropriate attitudes/behaviors in the organization", about half of the PwD co-workers disagreed or totally disagreed with this fact (51\%), while $33.8 \%$ neither agreed nor disagreed. In the item "Living with PwD improves the organizational climate", part of the participants neither agreed nor disagreed with this fact (42\%).

Most of the PwD's co-workers agreed (92.7\%) that hiring PwD's contributes to the company's social responsibility. Similarly, in the study by Estevam et al. (2020), half of the sample reported that the inclusion of PwD's in the labor market is a matter of social responsibility and that everyone must ensure that this practice is fulfilled. Also, in the study of Vargas (2014), social responsibility was pointed out as the main reason for hiring PwD's.

Only a small proportion of PwD co-workers agreed (30\%) that PwD have more difficulty understanding or performing a task. These results are in line with those of the study by Doolabh (2018), which showed that most PwD co-workers agreed that PwD's are perfectly capable of understanding and performing tasks, provided they have the right working conditions. Only a small portion of PwD co-workers agreed (23.5\%) that PwD's have lower productivity, which is in line with the results of Silva et al. (2018) who showed that most managers (90\%), despite considering this group as people with limitations, also saw them with the potential to perform a good job. Regarding the fact that PwD stand out for their dedication to work, most PwD co-workers (59.9\%) agreed with this fact. Furthermore, Analuisa-Zumba et al. (2020) 
found that PwD's are seen by co-workers as dedicated, enthusiastic, and very committed to the assigned tasks.

Most of the PwD's co-workers agreed (79.3\%) that they could see the positive side of having a PwD in the workplace. Miranda and Souza (2020) concluded that the inclusion of PwD in companies is able to attract new types of consumers, besides promoting a social and psychological rehabilitation, since the feeling of productivity contributes to improve the quality of work life. Similarly, in the study by Lindsay et al. (2018), it was found that one of the benefits for companies in hiring PwD's is to gain competitive advantage through attracting diverse customers, customer loyalty and satisfaction, and inclusive work culture.

Most of the PwD's co-workers agreed (72.3\%) that hiring a PwD improves the organization's image with the workers. According to Scott et al. (2017), hiring people with autism or another type of disability improves the company's image with the employees, which has a very positive impact and promotes a culture of inclusion.

The majority of the PwD's co-workers agreed (83.4\%) that PwDs can adequately perform their jobs as long as they have the right working conditions. These results are in line with those of Sartika and Devita's study (2020) which showed that the PwD's work skills such as intellectual, emotional, and social skills were good. Thus, this suggests that these people can perfectly perform the job as long as they meet the appropriate conditions to do so.

\subsubsection{Emotional Intelligence}

Two-thirds of the PwD's co-workers (66.5\%) agreed that they easily recognize the PwD's emotions through their behavior and facial expressions. Also, $71.3 \%$ agreed with the fact that they are aware of the non-verbal messages they convey to the PwD, and these results coincide with those of Espinoza (2019) who concluded that for some bosses, PwDs are treated as very fragile and sensitive people. As a result, they are careful how they express themselves (verbally or non-verbally) to them. The majority (85.4\%) agreed that it helps the PwD feel better when they are unmotivated (sad); 89.2\% agreed that when PwDs talk about an important event in their life, they are sensitive to their feelings and emotions. Similarly, Mik-Meyer (2016) found that one of the main behaviors of colleagues with PwDs was being overprotective and helpful, as they were all very careful and delicate in dealing with these people on a daily basis, by always being attentive to their feelings and emotions. Most of the PwD's co-workers agreed (87.6\%) to recognize and understand the PwD's limitations. Espinoza (2019) found that the PwD's coworkers were aware of their limitations and helped them whenever they could because they need constant support. According to the author, this 
corresponds to a hierarchical view where employees have the perception that PwDs are dependent, not very competent, and slower.

\subsubsection{Interpersonal Communication}

The majority of the PwD co-workers agreed (83.4\%) that, in general, there is good communication with the PwD. These results are in line with those of Kitis et al. (2017) who concluded that the employee with intellectual disabilities is seen as communicative, sociable, honest, sincere, and punctual at work. The co-workers of the PwD disagreed that the PwD usually have problems in relationships with colleagues. Heera and Devi (2016), in turn, concluded that employers are usually concerned about the impact that the PwD's low performance may have on other employees and their ability to comply with rules within the organization, which may create problems in the relationship between team members. About half of the PwD's co-workers disagreed (51\%) that the PwD may adopt inappropriate attitudes/behaviors in the organization. However, some (33.8\%) neither agree nor disagree with this fact. In the study by Henao (2016), some colleagues reported having already felt some discomfort while working with PwDs, due to the fact that they had already behaved inappropriately in the organization.

Most of the PwD's co-workers agreed (76.1\%) that the PwD has contact/interaction with the different workers/departments. These results are different from those found in the study by Nota et al. (2013), which revealed that employers interacted very little with employees with disabilities, and when they did it was not directly, but rather through intermediaries. Just over half of the PwD co-workers agreed that living with the PwD improves the organization's climate $(54.1 \%)$. Also, Lanzo (2018) verified that the companies considered PwDs as valuable elements in the organization because they create a better working environment and their integration makes people around them realize what they are capable of doing, thereby eliminating unnecessary stigmas.

\subsubsection{Integration / Insertion in the Workplace}

$82.8 \%$ of PwD's co-workers agreed that the company aims to promote the social inclusion of PwD. In the study by Manguinhas (2016), it was found that the companies under study aim to include PwDs by perceiving their hiring in a very positive way.

A lower percentage of the PwD's co-workers (60.8\%) agreed that the company is structurally prepared to receive a PwD. The study by MilanovicDobrota (2018) concludes that the main barriers in hiring PwDs consist of the lack of professional experience of this group, the lack of incentives to hire them, and the need for physical adaptation of the work environment. Less than half of the PwD's co-workers (47.5\%) agreed that they made the necessary 
adaptations to receive the PwD. In the study by Silva et al. (2018), it was also found that most employees stated that companies have a good degree of qualification to meet the needs of employees with disabilities.

About half of the PwD's co-workers (55.4\%) disagreed that they had received training/information that would prepare them to work with a PwD. These results are in line with findings in the literature, which have shown that coworkers and managers of PwDs have not received training to work with this population (Carreras \& Moreno, 2011; Rosa et al., 2019). According to Rosa et al. (2019), this practice by the organization can be a major hindrance to the inclusion of PwD's in the workplace, as colleagues may not be prepared to train them properly or they might be unwilling to do so.

A majority of the PwD's co-workers agreed (71.7\%) that all co-workers accepted the PwD well. These results are in agreement with those of Silva et al. (2018) who reported that there was no difficulty in adaptation by other employees, and everyone accepted the PwDs.

In addition, a large percentage of the PwD's co-workers agreed (77.1\%) that the PwDs is well integrated into the organizational environment. According to Silva et al. (2018), this perspective varies based on the expectations of each employee.

\section{Conclusion}

The results showed that PwD's recognize their emotions when interacting with co-workers. The feeling/emotion that mostly characterizes the daily professional life of these people is pride.

However, despite knowing what generates an intense emotion, most of the interviewees were not clearly explicit in revealing their deeper emotions. The participants, for the most part, did not find the communication channels confusing. Furthermore, they reported that there was clear and direct communication when the company conveyed its values and vision. It is also concluded that the employer has the objective of promoting the social inclusion of $\mathrm{PwD}$ and is structurally prepared to receive these people, being up to date with the legislation in force. Moreover, it was verified that, although most PwD feel integrated, they suggest greater sensitivity from the employer, adapted work, and more accessibility in the workplace.

Regarding the PwD's co-workers, the present study revealed that the vast majority of the participants agreed that hiring the PwDs contributes to social responsibility. In addition, the results indicate that the majority of colleagues believe that the company aims to promote the social inclusion of PwD.

This study also showed that colleagues have a positive perception of the professional performance of PwD's, since they stated that they stand out for their dedication to work. The interviewed colleagues see the positive side 
of having a PwD in the workplace, which means that these colleagues consider it an advantage for employers to hire PwDs. In addition, colleagues agree that hiring a PwD improves the organization's image with customers and employees alike.

Taking into consideration that it is a subject of little knowledge and recent for many people, it was possible to create an insight into the subject for the PwD's themselves, as well as for their managers and colleagues, since broadening knowledge will be beneficial to both.

\section{References:}

1. Analuisa-Zumba, T., Román-Escobedo, V., \& González-Ramón, E. (2020). La inserción laboral de personas con discapacidad en el campo empresarial. Digital Publisher CEIT, 5(3), 38-48. https://doi.org/10.33386/593dp.2020.3.208.

2. Anand, P. \& Sevak, P. (2017). The role of workplace accommodations in the employment of people with disabilities. Journal of Labor Policy, 6(12), 1-20. https://doi.org/10.1186/s40173-017-0090-4.

3. Arándiga, A. (2009). La inteligência emocional de los padres y de los hijos. Ediciones Pirámide.

4. Barbra, M. \& Mutswanga, P. (2014). The Attitudes of Employers and Co-Workers towards the Employment of Persons with Disabilities in Zimbabwe. International Journal on Managerial Studies and Research, 2(3), 7-19. https://www.arcjournals.org/ijmsr/volume-2issue- $3 / 2$.

5. Borges, R., Almeida, J., Siqueira, T., \& Sobrinho, M. (2020). Inserção e permanência de surdos no mundo do trabalho: estudo exploratório em empresas de um município centro-oeste goiano. Revista Educação, Artes e Inclusão, 16 (1), 193-215. https://doi.org/10.5965/1984317816012020193.

6. Bringer, J., Johnston, L., \& Brackenridge, C. (2004). Maximising transparency in a doctoral thesis: The complexities of writing about the use of QSR*NVIVO within a grounded theory study. Qualitative Research, 4, 247-265. https://doi.org/10.1177/1468794104044434.

7. Carreras, S. \& Moreno, W. (2011). Perspectivas de la experiencia gerencial hacia empleados con discapacidad intelectual. Cuaderno de Investigación, 26, 183-199.

https://revistas.upr.edu/index.php/educacion/article/view/13324.

8. Coutinho, B., França, I., Coura, A., Medeiros, K., \& Aragão, J. (2017). Qualidade de vida no trabalho de pessoas com deficiência física. Trabalho, Educação e Saúde, 15(2), 561-573. https://doi.org/10.1590/1981-7746-sol00061. 
9. Doolabh, N. (2018). The employment of individuals with hearing impairment in the KwaZulu-Natal private sector: Current employers' perceptions and experiences (Dissertação de mestrado). University of Kwazulu-Natal: Westville Campus. https://researchspace.ukzn.ac.za/handle/10413/16701

10. Espinoza, V. (2019). Inclusión educativa universitaria para personas en condición de discapacidad intelectual y la visión social de las neurociencias (teoria informal). Educación, 28(54), 243-265. https://doi.org/10.18800/educacion.201901.012.

11. Estevam, J., Vianna, D., \& Fernandes, S. (2020). Inclusão da pessoa com deficiência no trabalho: estudo transversal. Brazilian Journal of Health Review, 3(4), 7766-7779. https://doi.org/10.34119/bjhrv3n4046.

12. Felizardo, P., Ronchi, F., Robaina, G., \& Paiva, E. (2016). Inclusão de pessoas com deficiência nas organizações e impacto no clima organizacional (CO). Revista da FAE, 1, 159-176. https://revistafae.fae.edu/revistafae/article/view/412.

13. Freitas, C., Pereira, J., Honório, L., \& Silva, W. (2017). A inserção de pessoas com deficiência no mercado de trabalho: Uma reflexão à luz da responsabilidade social empresarial. Economia e Gestão, 17(48), 98-118. http://dx.doi.org/10.5752/P.1984-6606.2017v17n48p98-118.

14. Galle, J. \& Mengden, P. (2016). Um olhar para a inclusão do deficiente no mercado de trabalho em Taquara. Revista de Administração de Empresas Eletrônica, 4, 1-28.

https://seer.faccat.br/index.php/administracao/article/view/396-

15. Gogoi, P. (2020). Application of SPSS Programme in the Field of Social Science Research. International Journal of Recent Technology and Engineering, 8(5), 2424-2427. https://doi.org/10.35940/ijrte.D9260.018520.

16. Gonçalves, J. (coord) \& Nogueira, J. (2012). O Emprego das Pessoas com Deficiências ou Incapacidade - Uma abordagem pela igualdade de oportunidades. MSSS - Gabinete de estratégia e planeamento. http://www.cartasocial.pt/pdf/emprego_pdi.pdf.

17. González-González, D., Gutiérrez-Barroso, J., González-Herrera, A., \& Márquez-Domínguez, Y. (2017). Inserción Laboral De Personas Con Discapacidad. European Scientific Journal, 13(29), 109-124. https://doi.org/10.19044/esj.2017.v13n29p109.

18. Hahn, A.K., Jackson, C., Simone, S., \& Nunes, N. (2018). Inclusão de pessoas com deficiência por empresas na região da Grande Florianópolis/SC. Revista Metropolitana de Sustentabilidade, 8(2), 102-118. 
https://revistaseletronicas.fmu.br/index.php/rms/article/view/1242/pd f.

19. Heera, S. \& Davi, A. (2016). Employer's Perspective Towards People with Disabilities, a Review of the Literature. The South East Asian Journal of Management, 10(2). 54-74.

http://journal.ui.ac.id/index.php/tseajm/article/view/5960/3681.

20. Henao, N. (2016). Impactos de la inclusión laboral en el clima organizacional (Dissertação de mestrado). Universidad EAFIT. http://hdl.handle.net/10784/8715.

21. Huang, I. C. \& Chen, R. K. (2015). Employing People With Disabilities in the Taiwanese Workplace Employers' Perceptions and Considerations. Rehabilitation Counseling Bulletin, 59(1), 43-54. https://doi.org/10.1177/00343552030460030101.

22. Kitis, A., Eraslan, U., Koc, V., Giresun, F., \& Usta, H. (2017) Investigation of Disability Level, Leisure Satisfaction, and Quality of Life in Disabled Employees. Social Work in Public Health, 32(2), 94101. https://doi.org/10.1080/19371918.2016.1188748.

23. Lanzo, R. (2018). Reclutamiento y selección de personas con discapacidad (Dissertação de mestrado). Universidad de La Laguna. https://repositorio.uesiglo21.edu.ar/handle/ues21/13789.

24. Leopoldino, C. \& Coelho, P. (2017). O processo de inclusão de autistas no mercado de trabalho. Economia e Gestão, 17(48), 141-156. https://doi.org/10.5752/P.1984-6606.2017v17n48p141-156.

25. Lieketseng, N. \& Lorenzo, T. (2016). Enhancing the Public Sector's Capacity for Inclusive Economic Participation of Disabled Youth in Rural Communities. African Journal of Disability, 5(1), 189. https://doi.org/10.4102/ajod.v5i1.189.

26. Linday, S., Cagliostro, E., \& Mortaji, N. (2019). Systematic review of the benefits of hiring people with disabilties. Journal of Occupational Rehabilitation, 28(4), 634-655. https://doi.org/10.1007/s10926-0189756-z.

27. Lorenzo, S. \& Silva, N. (2017). Contratação de Pessoas com Deficiência nas Empresas na Perspectiva dos Profissionais de Recursos Humanos. Revista Brasileira de Educação Especial, Marília, 23(3),345-360. https:// doi.org/10.1590/S141365382317000300003.

28. Manguinhas, M. (2016). Perspetiva dos empregadores face à integração socioprofissional de pessoas com Dificuldades Intelectuais e de Desenvolvimento (Dissertação de mestrado). Universidade de Évora. https://dspace.uevora.pt/rdpc/bitstream/10174/18584/1/

29. Mik-Meyer, N. (2016) Disability and 'care': Managers, employees and colleagues with impairments negotiating the social order of disability. 
Work, Employment \& Society, 30(6), 984-999. https://doi.org/10.1177/0950017015617677.

30. Milanovic-Dobrota, B. (2018). Barijere u zapošljavanju osoba sa intelektualnom ometenošću - percepcija poslodavaca. Specijalna edukacija i rehabilitacija (Beograd), 17(2), 189-212. https://doi.org/10.5937/specedreh17-16987.

31. Miranda, E. \& Souza, C. (2020). Dificuldades da inclusão de pessoas com deficiência no mercado de trabalho. Revista Multidisciplinar do Nordeste Mineiro, 1, 1-12. https://revistas.unipacto.com.br/storage/publicacoes/2020/413.

32. Nosenko-Stein, E. (2017). "They fear us because we are Other": attitudes towards disabled people in today's Russia. Salud Colectiva, 2, 157-170. https://doi.org/10.18294/sc.2017.1140.

33. Nota, L., Santilli, S., Ginevra, M., \& Soresi, S. (2013). Employer Attitudes Towards the Work Inclusion of People With Disability. Journal of Applied Research in Intellectual Disabilities, 27(6), 2-10. https://doi.org/ 10.1111/jar.12081.

34. Pinheiro, L. \& Dellatorre, R. (2015). Desafios da Inclusão de Pessoas com Deficiência no Mercado de Trabalho: Um Estudo sobre a Percepção dos Envolvidos. Perspectiva, Erechim, 39(148), 95-109. https://www.uricer.edu.br/site/pdfs/perspectiva/148_537.p.

35. Prates, J. (2019). A Integração Profissional de Pessoas com Deficiência Apoiada por Medidas Políticas (Dissertação de mestrado). Instituto Universitário de Lisboa. http://hdl.handle.net/10071/19076.

36. Quinn, M., Hunter, C., Sumanta Ray, S., Quadir, M., Sen, K., \& Cumming, R. (2016). The Double Burden: Barriers and Facilitators to Socioeconomic Inclusion for Women with Disability in Bangladesh. Disability, CBR \& Inclusive Development, 27(2). https://doi.org/10.5463/dcid.v27i2.474.

37. Ripat, J. \& Woodgate, R. (2017). The Importance of Assistive Technology in the Productivity Pursuits of Young Adults with Disabilities. Work, 57, 455-468. https://doi.org/10.3233/WOR172580.

38. Rosa, M., Santos, T., Palhares, J., \& Souza, A. (2019). Inclusive company? A comparative analysis between the discourses of disable workers and managers of a cooperative company. Revista Gestão e Planejamento, Salvador, 20, 218-238. https://doi.org/10.21714/21788030gep.v20.5688.

39. Roessler, R.T., Rumrill, P.D.J., Rumrill, S., Minton, D.L., Hendricks, D.J., Sampson, E., Stauffer, C., Scherer, M.J., Nardone, A., Leopold, A. et al. (2017). Qualitative Case Studies of Professional-Level Workers with Traumatic Brain Injuries: A Contextual Approach to Job 
Accommodation and Retention. Work, 58 (1), 3-14. https://doi.org/10.3233/WOR-162601.

40. Rohmer, O. \& Louvet, E. (2018). Implicit stereotyping against people with disability. Group Processes and Intergroup Relations. SAGE Publications, 21 (1), 127-140. https://doi.org/ff10.1177/1368430216638536ff. ffhal-02079289f.

41. Rueda, B. \& Andrade, L. (2016). La inclusión laboral de personas con discapacidad: Un estudio etnográfico en cinco Comunidades Autónomas de España. Archivos de Medicina (Manizales), 16(2), 279289. https://doi.org/10.30554/archmed.16.2.1720.2016.

42. Ruhindwa, A., Randall, C., \& Cartmel, J.L. (2016). Exploring the challenges experienced by people with disabilities in the employment sector in Australia: Advocating for inclusive practice- a review of literature. Journal of Social Inclusion, 7(1), 4. https://doi.org/10.36251/josi.99.

43. Santos, S. (2014). A Discriminação na Integração de Pessoas com Deficiência no Mercado de Trabalho (Dissertação de mestrado). Faculdade de Economia, Universidade do Porto. https://sigarra.up.pt/fep/en/pub_geral.show_file?pi_doc_id=27749.

44. Sartika, D. \& Devita, A. (2020). Employing people with disabilities: are they competent and performed? Jurnal Bisnis dan Manajemen, 21(1), 43-56. http://Journal.feb.unpad.ac.id/index.php/jbm.

45. Scott, M., Jacob, A., Hendrie, D., Parsons, R., Girdler, S., Falkmer, T., \& Falkmer, M. (2017). Employers' perception of the costs and the benefits of hiring individuals with autism spectrum disorder in open employment in Australia. Plos One, 12(5), 1-16. https://doi.org/10.1371/journal.pone.0177607.

46. Silva, E., Rolim, F., Santos, R., Silva, M., Melo, W., Santos, L., Neto, J., \& Santana, D. (2018). A acessibilidade e a inclusão da pessoa com deficiência nas empresas de Cajazeiras - PB. Informativo Técnico do Semiárido, 12(1), 1-9. https://doi.org/10.13140/RG.2.2.22749.15844.

47. Silva, N., Furtado, A., \& Andrade J. (2018). A Inclusão no Trabalho sob a Perspectiva das Pessoas com Deficiência Intelectual. Trends in Psychology, 26(2), 1017-1030. https://doi.org/10.9788/tp2018.2-17pt.

48. Shahin, S., Reitzel, M., Di Rezze, B., Ahmed, S., \& Anaby, B. (2020). Environmental Factors that Impact the Workplace Participation of Transition-Aged Young Adults with Brain-Based Disabilities: A Scoping Review. International Journal of Environmental Research and Public Health, 17(7), 2-24. https://doi.org/10.3390/ijerph17072378.

49. Sherbin, L. \& Kennedy, J. (2017). The Case for Improving Work for People with Disabilities Goes Way Beyond Compliance. Harvard 
Business Review, 1-6. https://hbr.org/2017/12/the-case-for-improvingwork-for-people-with-disabilities-goes-way-beyond-compliance.

50. Sundar, V., O’Neill, J., Houtenville, A., Phillips, K., \& Keirns, T. (2018). Striving to work and overcoming barriers: Employment strategies and successes of people with disabilities. Journal of Vocational Rehabilitation, 48, 93-109. https://doi.org/10.3233/JVR170918.

51. Vaquerano, J. R. (2019). Incorporación de personas con discapacidad al mercado laboral en la ciudad de San Miguel. Ciencia, Cultura y Sociedad, 4(2), 24-3. https://doi.org/10.5377/ccs.v4i2.6671.

52. Vasconcelos, F., \& Maranhão, T. (2020). Os Desafios das Empresas em Contratar Pessoas com Deficiência: Revisão Sistemática da Literatura. Revista Multidisciplinar e de Psicologia, 14(51), 754-773. https://doi.org/10.14295/idonline.v14i51.2633.

53. Vargas, R. (2014). A Inserção no Mercado de trabalho de Pessoas em Situação de Desvantagem: Perspetivas dos Empresários e Satisfação do trabalhador nas empresas de São Miguel (Dissertação de mestrado). Universidade Fernando Pessoa.

https://bdigital.ufp.pt/bitstream/10284/6969/1/DM_Raquel\%20Varga s.pdf. 552.

54. Zappella, E. (2015). Employers' attitudes on hiring workers with intellectual disabilities in small and medium enterprises: An Italian research. Journal of Intellectual Disabilities, 19(4), 1-12. https://doi.org/10.1177/1744629515580883. 